UDC 314.7(476)

LBC $60.54+60.7$

\title{
MIGRATION TENETS OF MAIN SOCIO-DEMOGRAPHIC GROUPS OF THE POPULATION OF BELARUS: SOCIOLOGICAL ANALYSIS
}

\author{
Mikchail I. Artyukhin \\ Institute of Sociology of the National Academy of Sciences of Belarus, Minsk, Republic of Belarus \\ Sergey A. Pushkevich \\ Institute of Sociology of the National Academy of Sciences of Belarus, Minsk, Republic of Belarus \\ Ella M. Shurok \\ Institute of Sociology of the National Academy of Sciences of Belarus, Minsk, Republic of Belarus
}

\begin{abstract}
The article deals with the migration of the population as a socio-economic, socio-political and sociocultural phenomenon. The authors carry out the analysis of the migration situation in Belarus and define its ambiguous character. The researchers show that starting from 2016 negative trends began to manifest themselves increasingly in the external migration of the population of Belarus. As a result of the collapse of the main migration indicators, the coefficient of compensation for natural loss of the population due to the positive migration balance fell sharply: in 2017 it amounted to only $23.1 \%$. The paper demonstrates that the need for multidimensional knowledge of the socioeconomic mechanisms of migration in the context of modern threats to national security has led to the demand for sociological research in the field of migration. This is especially true for studies that determine the main characteristics and typology of migration behavior of the main socio-demographic groups. The article presents the results of monitoring sociological research conducted by Institute of Sociology of the National Academy of Sciences of Belarus for the period 2010-2018. The data of these studies indicate a fairly high level of potential external migration of the population of the Republic of Belarus. To the greatest extent, migration activity is a characteristic of young age respondents. In this regard, the authors conclude that the increasing importance of migration in the political, economic and demographic development of society determines the need to develop adequate challenges of the state migration policy and socioeconomic mechanisms for the effective regulation of migration processes.

Key words: migration of population, sociology of migration, socio-demographic group, migration tenet, migration behavior, socio-economic factors of migration, state migration policy.
\end{abstract}

\section{МИГРАЦИОННЫЕ УСТАНОВКИ ОСНОВНЫХ СОЦИАЛЬНО-ДЕМОГРАФИЧЕСКИХ ГРУПП НАСЕЛЕНИЯ БЕЛАРУСИ: СОЦИОЛОГИЧЕСКИЙ АНАЛИЗ}

\author{
Михаил Иванович Артюхин \\ Институт социологии НАН Беларуси, г. Минск, Республика Беларусь \\ Сергей Александрович Пушкевич \\ Институт социологии НАН Беларуси, г. Минск, Республика Беларусь \\ Элла Михаловна Щурок \\ Институт социологии НАН Беларуси, г. Минск, Республика Беларусь
}


Аннотация. В статье рассматривается миграция населения как социально-экономическое, социально-политическое и социокультурное явление. Проведен анализ сложившейся в Беларуси миграционной ситуации и определен ее неоднозначный характер. Показано, что начиная с 2016 г. во внешней миграции населения Беларуси все в большей мере начали проявляться отрицательные тенденции. В результате обвала основных миграционных показателей резко снизился коэффициент компенсации естественной убыли населения за счет положительного сальдо миграции: в 2017 г. он составил всего 23,1%. Потребность в многоаспектном познании социально-экономических механизмов миграции населения в контексте современных угроз национальной безопасности обусловила востребованность социологических исследований в области миграции. Особенно это относится к исследованиям, определяющим ключевые характеристики и типологию миграционного поведения основных социально-демографических групп населения. В статье представлены результаты мониторинговых социологических исследований, проведенных Институтом социологии НАН Беларуси за период 2010-2018 годов. Данные этих исследований говорят о достаточно высоком уровне потенциальной внешней миграции населения Республики. В наибольшей степени миграционная активность свойственна респондентам молодых возрастов. В связи с этим авторы делают вывод о том, что увеличение значимости миграции в политическом, экономическом и демографическом развитии общества определяет необходимость выработки адекватной вызовам времени государственной миграционной политики и социально-экономических механизмов эффективного регулирования миграционных процессов.

Ключевые слова: миграция населения, социология миграций, социально-демографическая группа, миграционная установка, миграционное поведение, социально-экономические факторы миграции, государственная миграционная политика.

Как свидетельствует мировой опыт, миграционные процессы имеют неоднозначные последствия для политического, социально-экономического и демографического развития любого государства. При возникновении масштабных миграционных потоков и усилении их стихийности могут ощутимо проявиться непредвиденные угрозы безопасности стабильного развития не только для отдельной страны, но и целых регионов, какие ранее не могли даже осознаваться по своим последствиям в качестве катастрофических и необратимых.

Исследователи, анализируя угрозы национальной безопасности, которые исходят от миграции населения, выделяют три уровня: макросистемный, мезосистемный (региональный) и микросистемный [Ткачева 2010].

Примером макросистемного уровня миграционной безопасности может стать миграционный кризис в Европе, который был порожден событиями Арабской весны 2011 г., ставшими началом непрекращающегося вала беженцев и вынужденных мигрантов из стран Северной Африки и Ближнего Востока, хлынувших в развитые страны ЕС. Этот миграционный кризис приобрел характер глобального и определил серьезные геополитические, экономические и демографические угрозы. По заключениям экспертов по своим параметрам и последствиям эти угрозы могут оказаться более опасными и разрушительными для стран $\mathrm{EC}$, чем, например, экономический кризис, а их преодоление потребует усилий нескольких поколений. Это объясняется тем, что миграционные потоки плохо моделируются и регулируются, так как чаще всего являются стихийными и в большинстве случаев приобретают черты надгосударственного характера.

Мезосистемный и микросистемный уровни миграционной безопасности более всего характерны для отдельного государства и затрагивают важнейшие сферы его социально-экономического и демографического развития.

Увеличение значимости миграции в политическом, экономическом и демографическом развитии общества определило необходимость выработки действенной государственной миграционной политики и социально-экономических механизмов эффективного регулирования миграционных процессов. Последнее не составило исключения и для Беларуси, где за годы суверенного развития была создана необходимая законодательная основа государственной миграционной политики и реализован ряд целевых государственных программ в области миграционной и демографической безопасности. Результатом этих усилий стала долговременная стабильная миграционная ситуация. С 1994 г. и по настоящее время в стране наблюдается положительное сальдо внешней миграции населения. Только за 2000-2017 гг. суммарный миграционный прирост населения Республики Беларусь составил 153,9 тыс. человек. С 2013 по 2016 г. положительное сальдо внешней мигра- 


\section{БЕЛОРУССКАЯ АКАДЕМИЧЕСКАЯ СОЦИОЛОГИЯ}

ции полностью восполняло естественную убыль населения. Следует отметить, что это стало возможным не только за счет стабильной миграционной ситуации, но и благодаря успешной реализации ряда национальных программ в области демографической безопасности.

Однако в последние годы миграционная ситуация в Беларуси начинает приобретать черты кризисного состояния и требует, несмотря на положительный опыт предыдущей пятилетки, особого внимания властных структур. Переломным в области миграции стал 2015 год. Статистические данные этого года определили начало отрицательных тенденций во внешней миграции населения Беларуси. Так, численность прибывших в Республику мигрантов уменьшилась с 28,4 тыс. чел. в 2015 г. до 18,9 тыс. чел. (-33,5\%) в 2017 г., а численность выбывших, наоборот, увеличилась с 9855 чел. в 2015 г. до 15087 чел. в 2017 г. (+53,1 \%). Это привело к тому, что миграционный прирост населения в 2017 г. по сравнению с 2015 г. снизился в 4,8 раза, составив в 2017 г. всего 3,9 тыс. чел. (рис. 1).

В результате обвала основных миграционных показателей резко снизился коэффициент компенсации естественной убыли населения за счет положительного сальдо миграции: в 2017 г. он составил всего 23,1 \%. Последнее, наряду с ростом отрицательных показателей естественной убыли населения, явилось одним из факторов уменьшения общей численности населения Республики в последние годы.

Не менее актуальной в настоящее время является задача совершенствования системы регулирования внешней трудовой миграции и минимизации ее негативных последствий для ряда отраслей национальной экономики. В этой связи следует отметить, что фактические масштабы внешней трудовой миграции трудноопределимы. Так, по данным Департамента по гражданству и миграции Министерства внутренних дел Республики Беларусь, основанным на обследованиях домашних хозяйств, число граждан Беларуси, которые находятся за пределами страны и осуществляют там трудовую деятельность, равна примерно 300 тыс. чел. ежегодно [По данным МВД... web].

Основным «потребителем» белорусских трудовых мигрантов является Россия. По данным Главного управления по вопросам миграции МВД Российской Федерации в 2017 г. численность граждан Республики Беларусь, прибывших в Россию с целью работы по найму, составила более 120 тыс. человек [Сведения... web]. Несомненно, такой масштабный ежегодный отток белорусских специалистов только в Россию приводит к снижению потенциала трудовых ресурсов страны и отрицательно влияет на формирование национального рынка труда.

Как показывает анализ, миграционная ситуация в регионах Республики также не может быть названа оптимальной. В 2017 г. миграционный прирост населения наблюдался только в г. Минске (5 337 чел.) и Минской области (7 037 чел.). Все остальные регионы Республики показывали отрицательное миграционное сальдо, что и определило в совокупности с естественной убылью сокращение численности их населения (см. рис. 2).

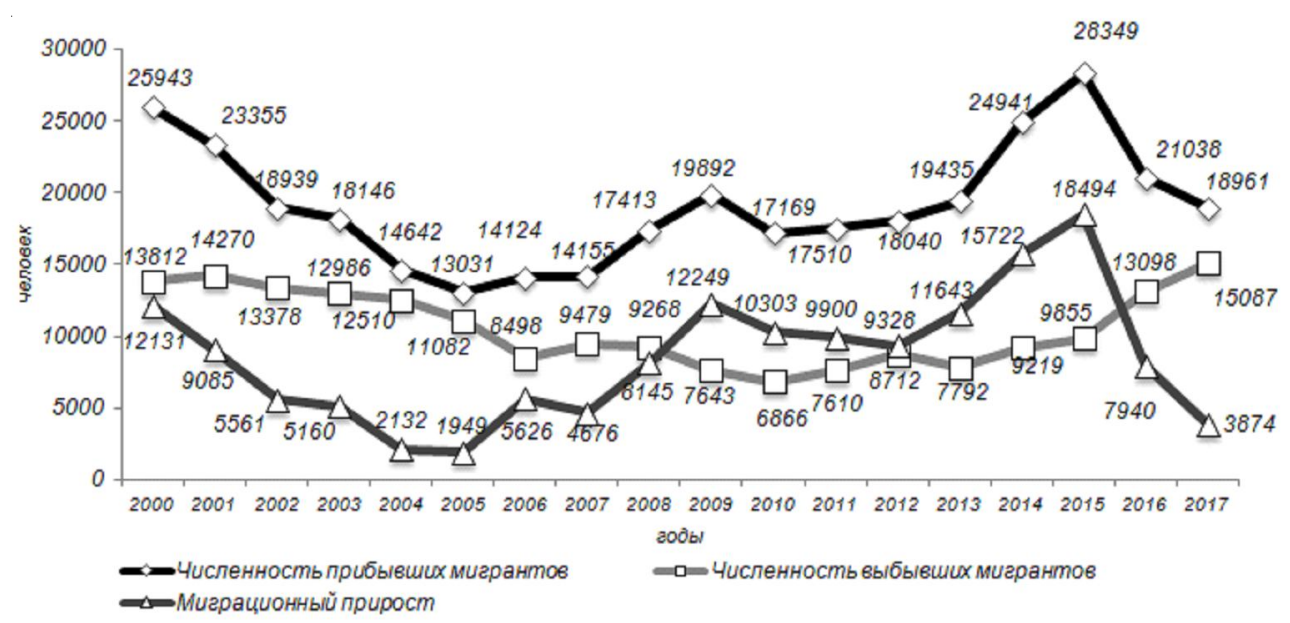

Рис. 1. Динамика внешней миграции населения Республики Беларусь за период 2000-2017 гг. [Миграция... 2013; 2017; 2018; Основные итоги... 2009; 2010; 2011; 2012; 2014; 2015; 2016]. 
Наблюдающиеся в последнее время негативные тенденции миграционного и демографического развития Беларуси вызвали острую потребность в социологических исследованиях в области миграционной и демографической безопасности. Особое значение данные исследования имеют для выявления социально-демографического состава миграционных потоков, а также структуры социально-экономических и психологических факторов, формирующих миграционное поведение основных социальнодемографических групп населения страны.

Институт социологии НАН Беларуси с 2006 г. проводит мониторинг миграционных установок населения Республики Беларусь. Данные репрезентативных республиканских социологических исследований говорят о достаточно высоком уровне потенциальной внешней миг- рации населения Республики. Так, за период 2014-2017 гг. существенно выросла доля респондентов, намеренных эмигрировать в зарубежные страны: с 5,6 \% в 2014 г. до 15,7 \% в 2017 году. Однако в 2018 г. наблюдается снижение этой доли респондентов до 11,4 \% (рис. 3).

По данным социологического исследования, проведенного летом 2018 г., среди зарубежных стран, в которые респонденты намерены эмигрировать, лидируют США - 16,6 \%, Германия $-15,4 \%$, Россия $-14,9 \%$, Польша $-13,1 \%$. Предпочтения респондентов для выезда за границу с целью временной работы распределились следующим образом: Польша - 23,7 \%, Россия $20,4 \%$, Германия - 10,8 \%, США - 9,7 \%.

Анализ социально-демографической структуры потенциальных мигрантов показывает, что она во многом различается в зави-

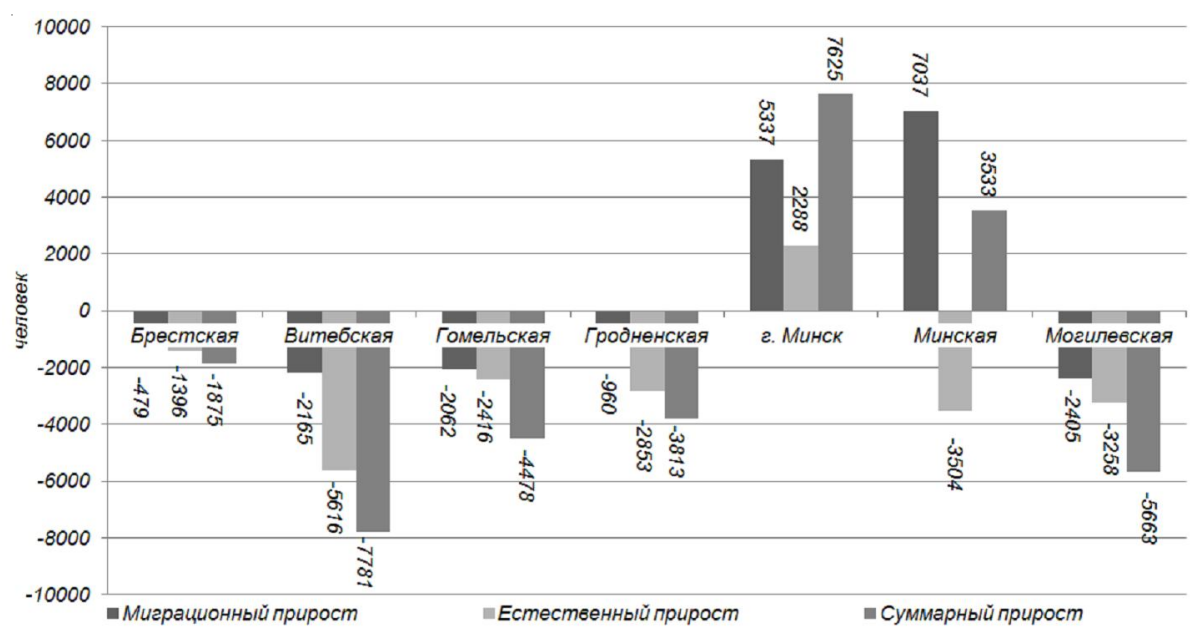

Рис. 2. Миграционный, естественный и суммарный прирост населения регионов Беларуси по итогам 2017 г. [Миграция... 2018; О естественном движении населения... 2018]

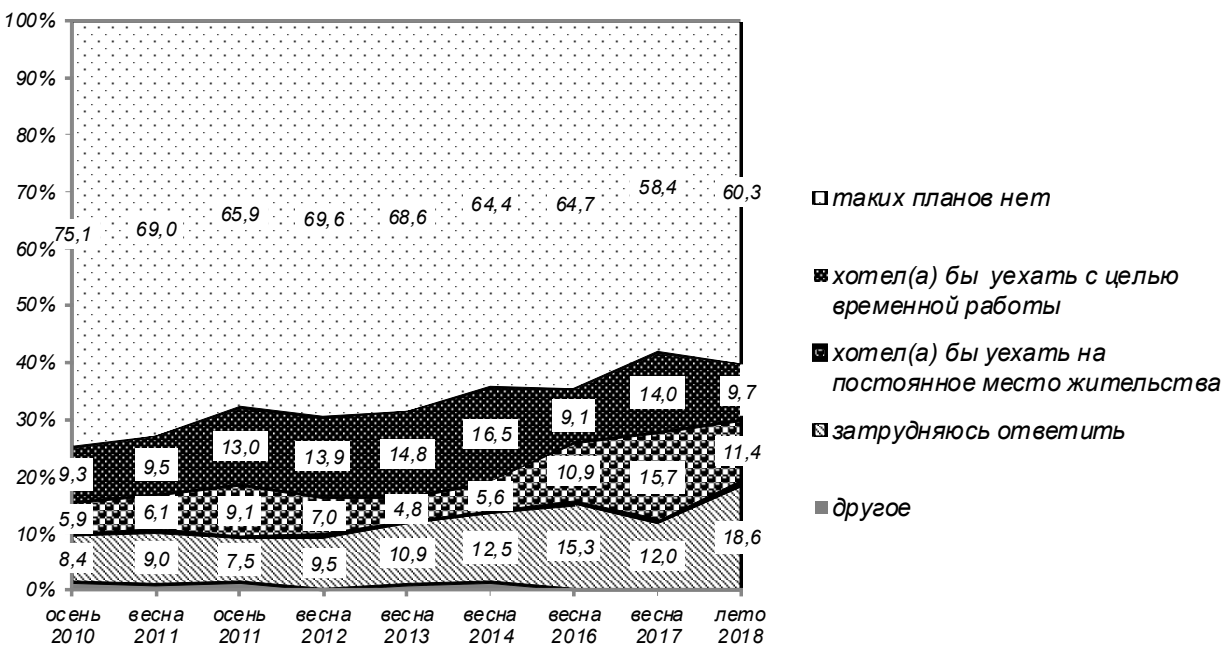

Рис. 3. Динамика распределения ответов на вопрос: «Хотели бы Вы уехать из Беларуси?» 


\section{БЕЛОРУССКАЯ АКАДЕМИЧЕСКАЯ СОЦИОЛОГИЯ}

симости от дифференциации респондентов по полу, возрасту, уровню образования, виду занятости и социальному положению.

На основе данных опроса, проведенного летом 2018 г., выявлено, что среди респондентов-мужчин уехать на постоянное место жительства за границу хотели бы в 2018 г. 13,2\% (16,9 \% в 2017 г., 12,6 \% в 2016 г.), а среди женщин - в 2018 г. 9,8 \% (14,7 \% в 2017 г., 9,5 \% в 2016 г.). Среди респондентов-женщин доля желающих уехать из Беларуси с целью временной работы составляет в 2018 г. 7,8\% (11,3\% в 2017 г., 6,0 \% в 2016 г.), а среди мужчин - 12,0 \% $(17,1 \%$ в 2017 г., $12,7 \%$ в 2016 г.) (рис. 4, 5).

На рисунках 6-8 представлена миграционная активность респондентов по различным возрастным группам, полученные данные свидетельствуют о том, что степень миграцион- ной активности среди респондентов тем выше, чем они моложе. В старших возрастных группах миграционная активность респондентов снижается и практически сходит на нет в предпенсионном и пенсионном возрасте. Можно посмотреть тенденции в разные временные периоды для респондентов в возрасте до 29 лет: выехать за границу на постоянное место жительства планировали в 2018 г. - 21,8 \%; в 2017 г. $-28,0 \%$; в 2016 г. $-19,6 \%$.

Эта зависимость наблюдается и в области внешней трудовой миграции. Так, доля респондентов в возрасте до 29 лет составила в 2018 г. 15,3\% (16,7\% в 2016 г., 18,7\% в 2017 г.); в возрасте 30-49 лет - 11,8 \% (8,9 \% в 2016 г., 17,6 \% в 2017 г.); в предпенсионном и пенсионном возрасте- 4,2 \% (3,9 \% в 2016 г., $7,7 \%$ в 2017 г.) (см. рис. 6-8).

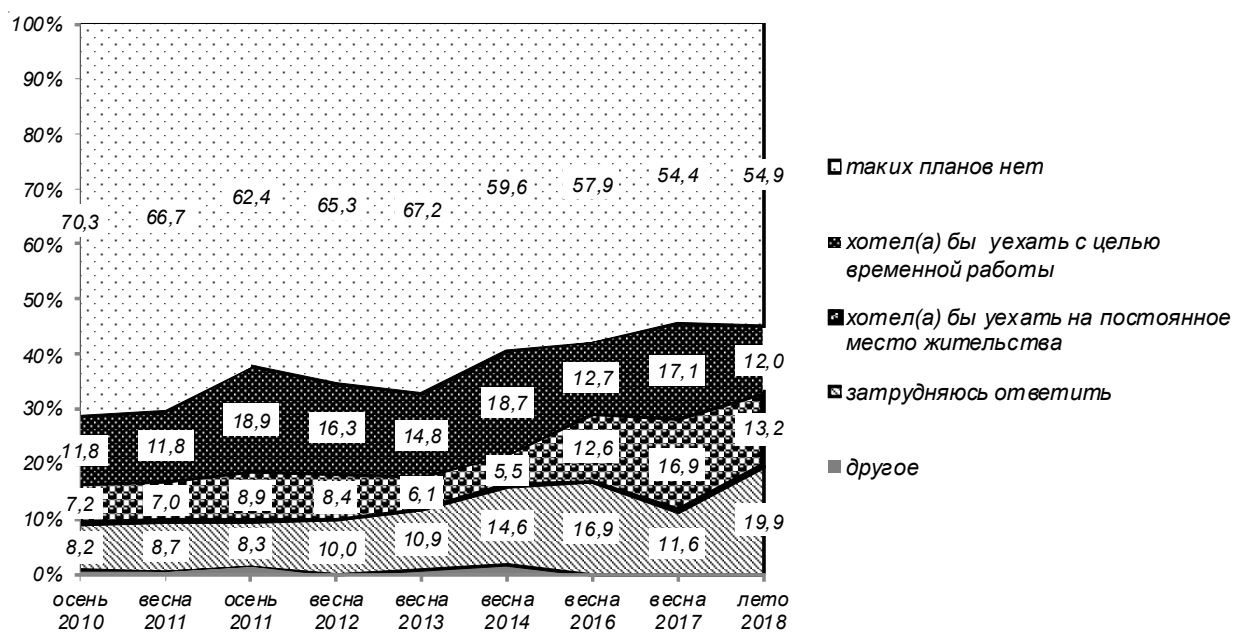

Рис. 4. Распределение ответов респондентов-мужчин на вопрос: «Хотели бы Вы уехать из Беларуси?», \%

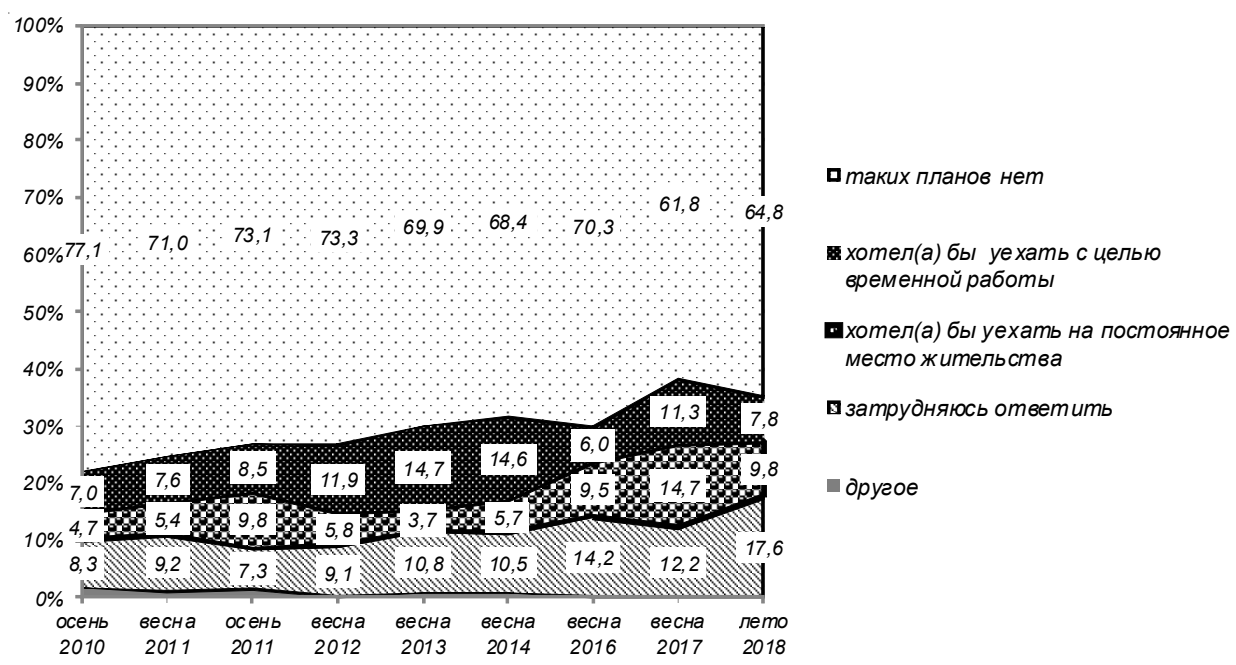

Рис. 5. Распределение ответов респондентов-женщин на вопрос: «Хотели бы Вы уехать из Беларуси?», \% 
М.И. Артюхин, С.А. Пушкевич, Э.М. Щурок. Миграционные установки социально-демографических групп

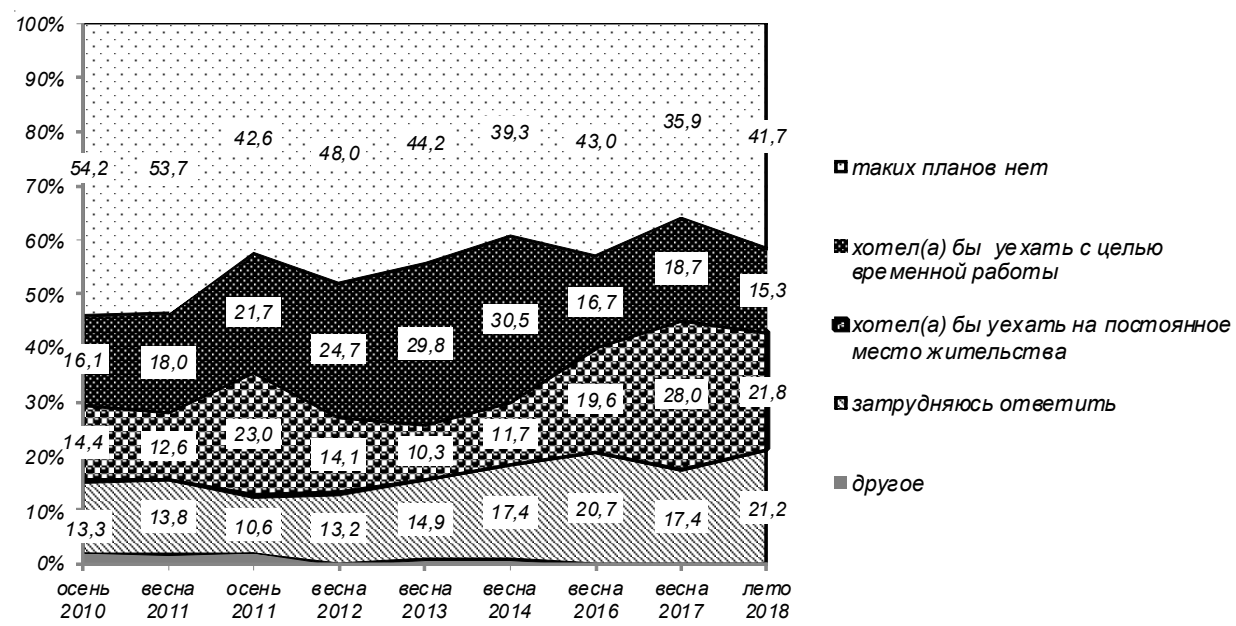

Рис. 6. Распределение ответов респондентов в возрасте до 29 лет на вопрос: «Хотели бы Вы уехать из Беларуси?», \%

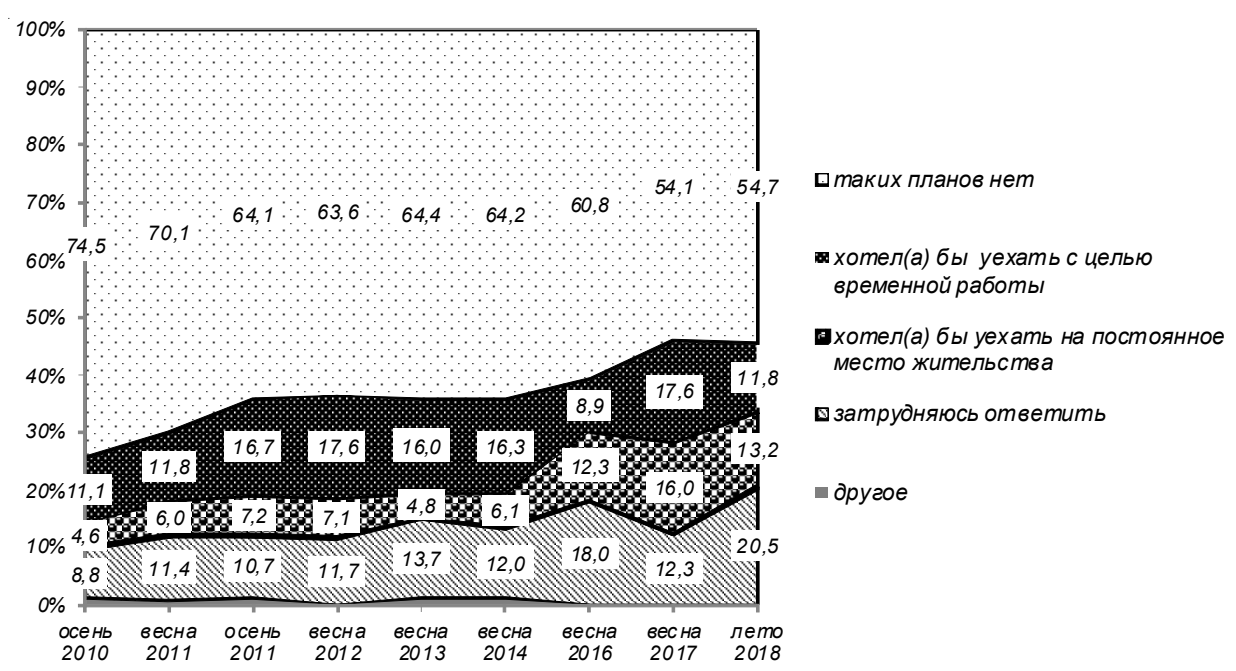

Рис. 7. Распределение ответов респондентов в возрасте 30-49 лет на вопрос: «Хотели бы Вы уехать из Беларуси?», \%

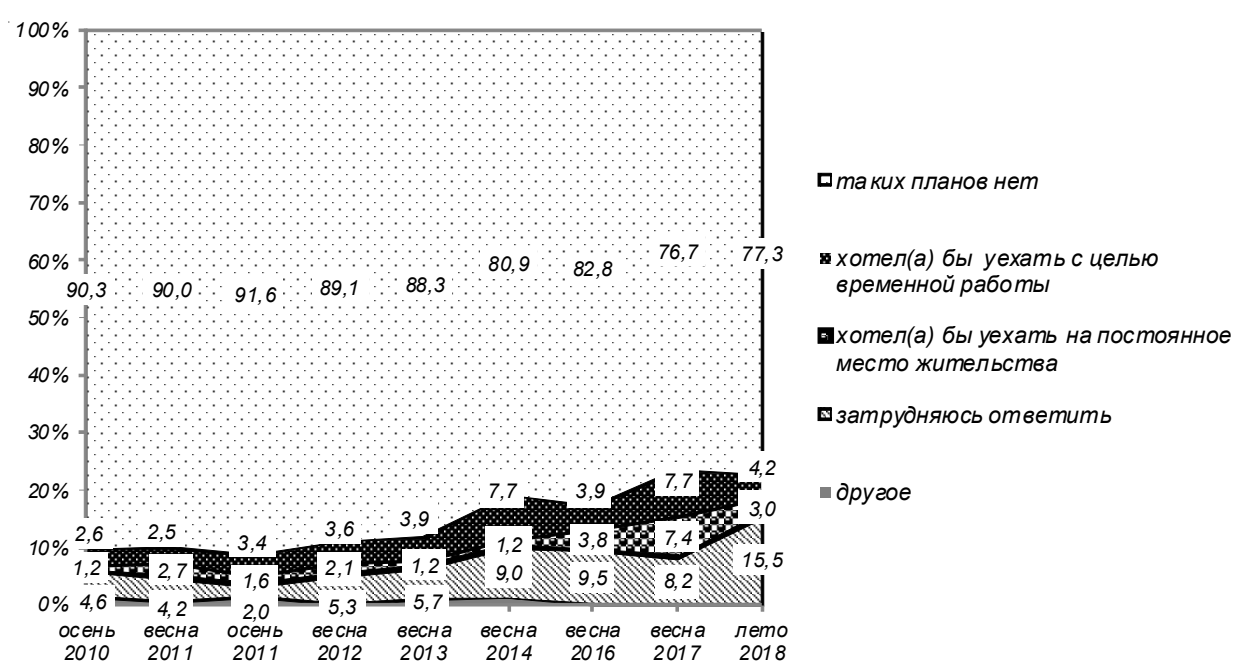

Рис. 8. Распределение ответов респондентов в возрасте 50 лет и старше на вопрос: «Хотели бы Вы уехать из Беларуси?», \% 


\section{БЕЛОРУССКАЯ АКАДЕМИЧЕСКАЯ СОЦИОЛОГИЯ}

В группах по уровню образования доля респондентов, намеренных эмигрировать из страны, представлена следующим образом: общее среднее образование: в 2018 г. - 12,6\%, 2017 г. - 15,4 \%, 2016 г. - 11,7 \%; среднее специальное образование: в 2018 г. - 13,3\%, 2017 г. - 15,7 \%, 2016 г. - 10,0 \%; высшее об- разование: в 2018 г. - 11,8 \%, 2017 г. - 19,8 \%, 2016 г. - 13,7 \%. Отметим здесь, что за последние два года наиболее резкое снижение потенциальных эмигрантов отмечено у респондентов, имеющих высшее образование, с $19,8 \%$ в 2017 г. до $11,8 \%$ в 2018 году (рис. 9-11).

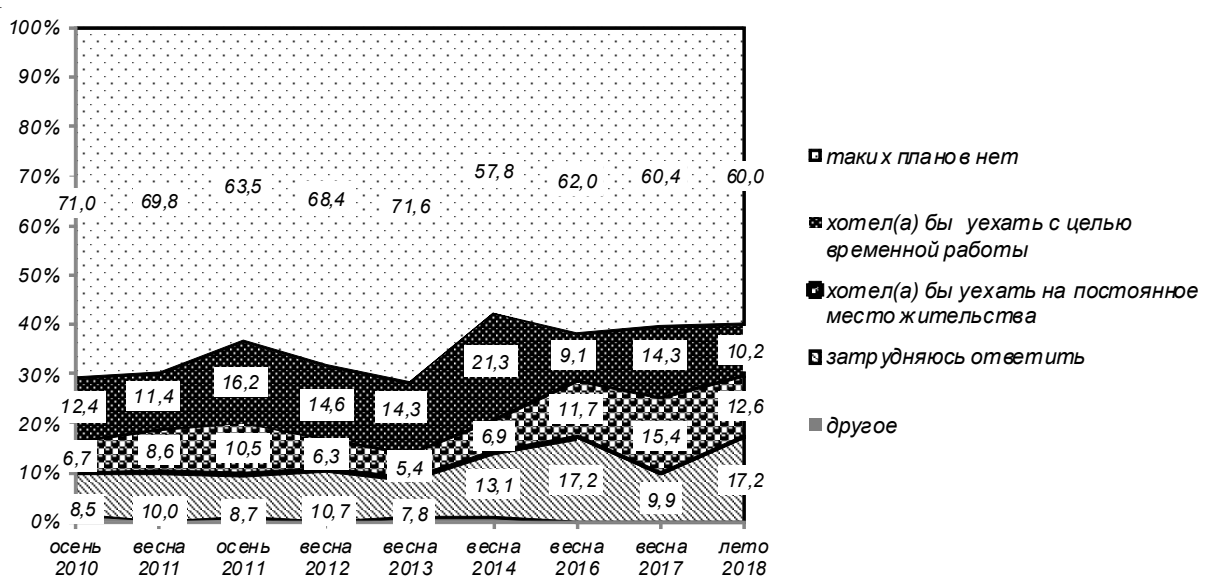

Рис. 9. Распределение ответов респондентов с общим средним образованием на вопрос:

«Хотели бы Вы уехать из Беларуси?», \%

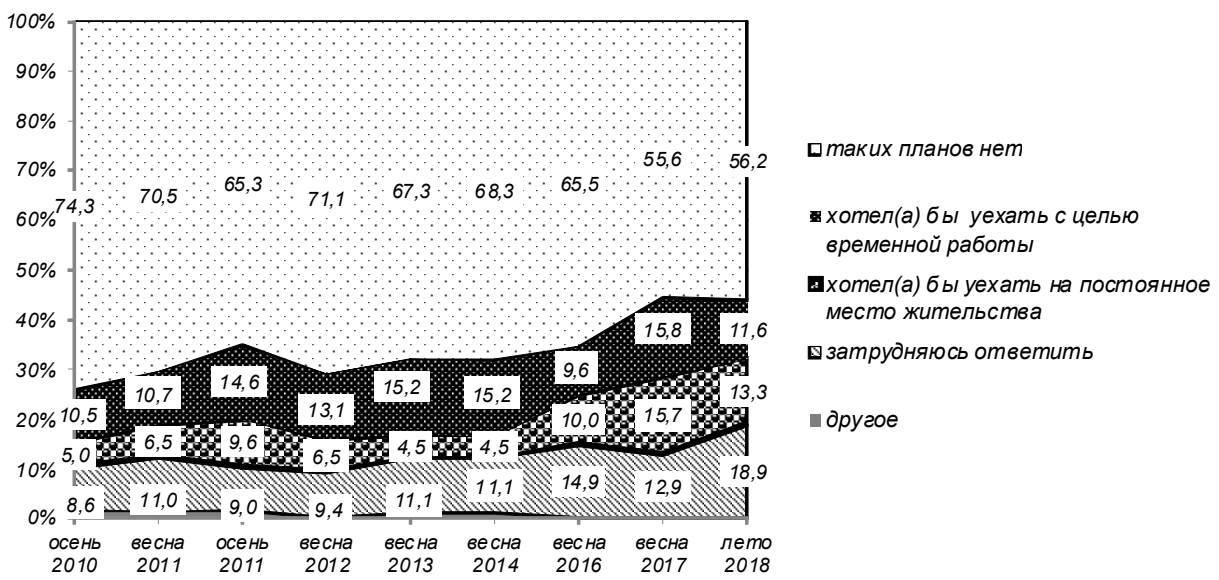

Рис. 10. Распределение ответов респондентов со средним специальным образованием на вопрос: «Хотели бы Вы уехать из Беларуси?», \%

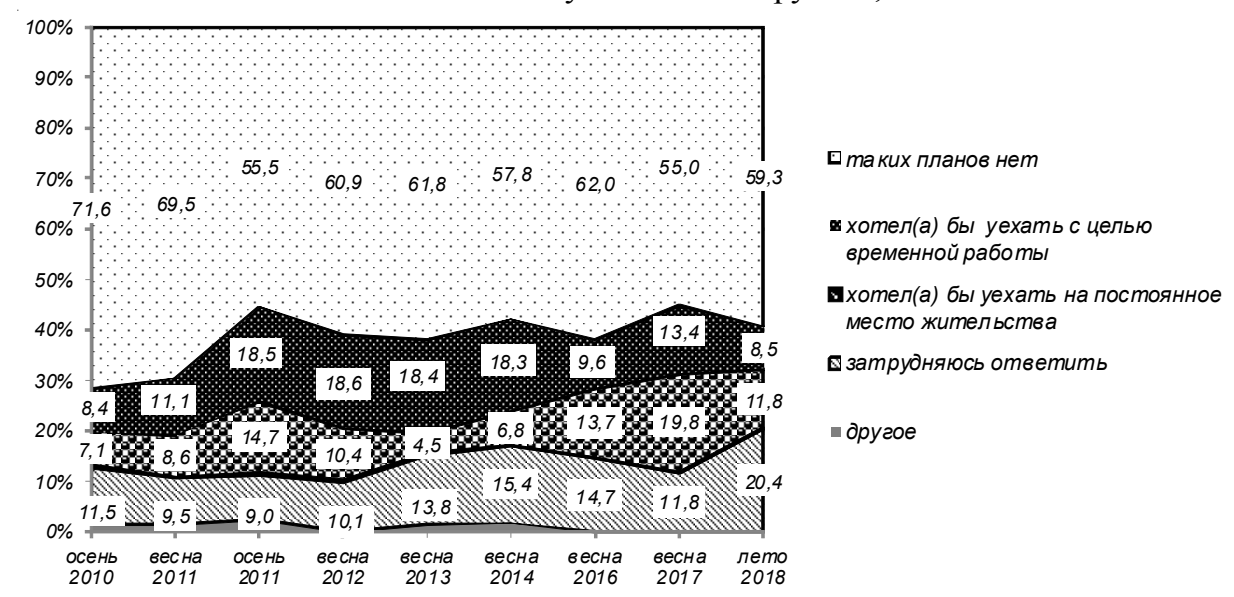

Рис. 11. Распределение ответов респондентов с высшим и незаконченным высшим образованием на вопрос: «Хотели бы Вы уехать из Беларуси?», \% 
Анализ миграционной активности респондентов, нацеленных на трудовую миграцию, различается и зависит от уровня образования. Приведем конкретные данные: среди респондентов, имеющих общее среднее образование, доля желающих поработать за границей составила в 2018 г. 10,2 \% (14,3 \% в 2017 г., 9, 1 \% в 2016 г.), среднее специальное образование $11,6 \%$ (15,8 \% в 2017 г., 9,6 \% в 2016 г.), высшее образование - 8,5\% (13,4\% в 2017 г., 9,6 \% в 2016 г.) (рис. 9-11).

Динамика и структура миграционных намерений респондентов в зависимости от их социально-профессионального положения представлены в таблице 1. Как видим из данных этой таблицы, миграционные намерения респондентов различных социально-профессиональных групп существенно различаются. Так, среди учащихся (студентов) доля потенциальных эмигрантов составила 28,8\%. У предпринимателей, фермеров, самозанятых - 22,0 \%. Среди рабочих промышленности, транспорта, строительства - 10,3\%. Наименьшая доля тех, кто думает выехать за границу на постоянное место жительства, наблюдается среди крестьян, рабочих сельского хозяйства $-6,2 \%$.

Среди тех, кто желает выехать за границу с целью временной работы, наблюдается более равномерное распределение. Из числа социально-профессиональных групп к наиболее активными в этом виде миграции мож- но отнести учащихся (студентов), среди которых 15,1 \% намерены поработать за границей; а также предпринимателей, фермеров, самозанятых (15,0 \%). Наименьшая доля респондентов, имеющих планы поработать за границей, - среди служащих, специалистов производственной сферы (инженер, технолог и т. д.) $-8,5 \%$.

По данным опроса, проведенного летом 2018 г., основной причиной выезда за границу на постоянное место жительства респонденты назвали невозможность обеспечить себе в Беларуси достойную жизнь - 58,3 \%. Навтором месте - желание улучшить свое материальное положение - 48,4 \%, на третьем желание обеспечить будущее своим детям, дать им хорошее образование - 39,4 \%, на четвертом - неопределенность профессиональных и жизненных перспектив - 26,5% (см. рис. 12).

К основным причинам своего намерения выехать за границу с целью временной работы респонденты отнесли: желание улучшить свое материальное положение - 61,5 \%; желание обеспечить будущее детям, дать им хорошее образование - 37,8 \%; желание посмотреть мир, пожить и поработать в другой стране - 32,2\% (см. рис. 13).

Ключевые мотивы желания выехать за границу на постоянное место жительства у основных социально-профессиональных групп населения Беларуси представлены в таблице 2.

Таблиц̧а 1

\section{Распределение ответов респондентов}

в зависимости от их профессии, вида занятости, сферы деятельности и социального положения на вопрос: «Хотели бы Вы уехать из Беларуси?», \% от числа ответивших (опрос 2018 г.)

\begin{tabular}{|c|c|c|c|c|}
\hline Социально-профессиональное положение & $\begin{array}{c}\text { Хотел бы уехать за } \\
\text { границу на постоян- } \\
\text { ное место жительства }\end{array}$ & $\begin{array}{c}\text { Хотел бы выехать } \\
\text { за границу с целью } \\
\text { временной работы }\end{array}$ & $\begin{array}{c}\text { Таких } \\
\text { планов } \\
\text { нет }\end{array}$ & $\begin{array}{l}\text { Затрудня- } \\
\text { юсь отве- } \\
\text { тить }\end{array}$ \\
\hline Руководители разного уровня & 14,3 & 10,4 & 56,5 & 18,8 \\
\hline $\begin{array}{l}\text { Рабочий (промышленности, транспорта, строи- } \\
\text { тельства и др.) }\end{array}$ & 10,3 & 13,0 & 56,1 & 20,6 \\
\hline Крестьянин, рабочий сельского хозяйства & 6,2 & 12,3 & 56,8 & 24,7 \\
\hline $\begin{array}{l}\text { Служащий, специалист производственной сфе- } \\
\text { ры (инженер, технолог и т. д.) }\end{array}$ & 14,0 & 8,5 & 53,5 & 24,0 \\
\hline $\begin{array}{l}\text { Служащий, специалист непроизводственной } \\
\text { сферы (учитель, врач и т. д.) }\end{array}$ & 15,7 & 10,2 & 56,3 & 17,8 \\
\hline $\begin{array}{l}\text { Предприниматель, фермер, самозанятый (инди- } \\
\text { видуальная трудовая деятельность) }\end{array}$ & 22,0 & 15,0 & 51,0 & 12,0 \\
\hline Учащийся, студент & 28,8 & 15,1 & 34,2 & 21,9 \\
\hline Другие & 5,6 & 6,3 & 75,5 & 12,6 \\
\hline
\end{tabular}




\section{БЕЛОРУССКАЯ АКАДЕМИЧЕСКАЯ СОЦИОЛОГИЯ}

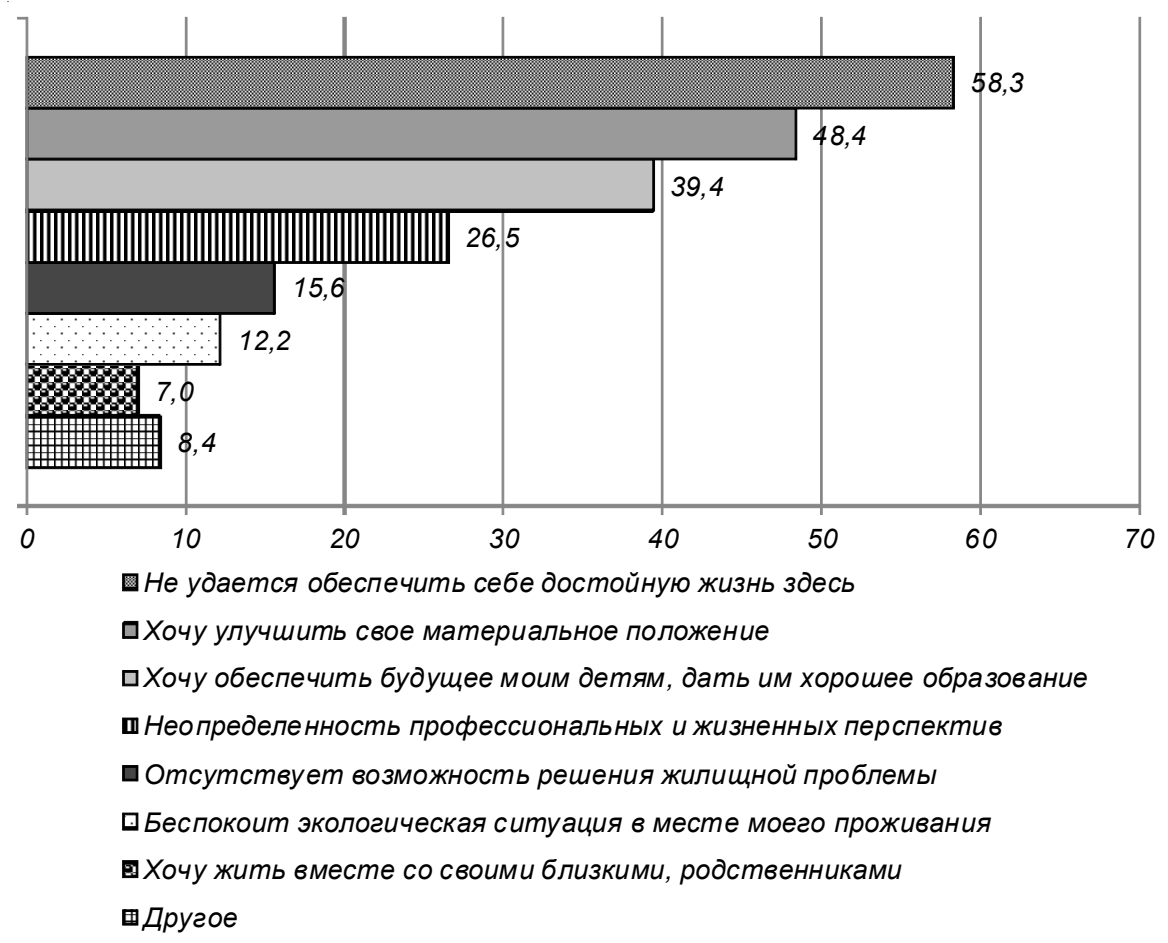

Рис. 12. Основные причины желания выезда из страны на постоянное место жительства, \%

Примечание. Сумма составляет более 100,0 \%, поскольку респонденты имели возможность выбрать несколько вариантов ответов.

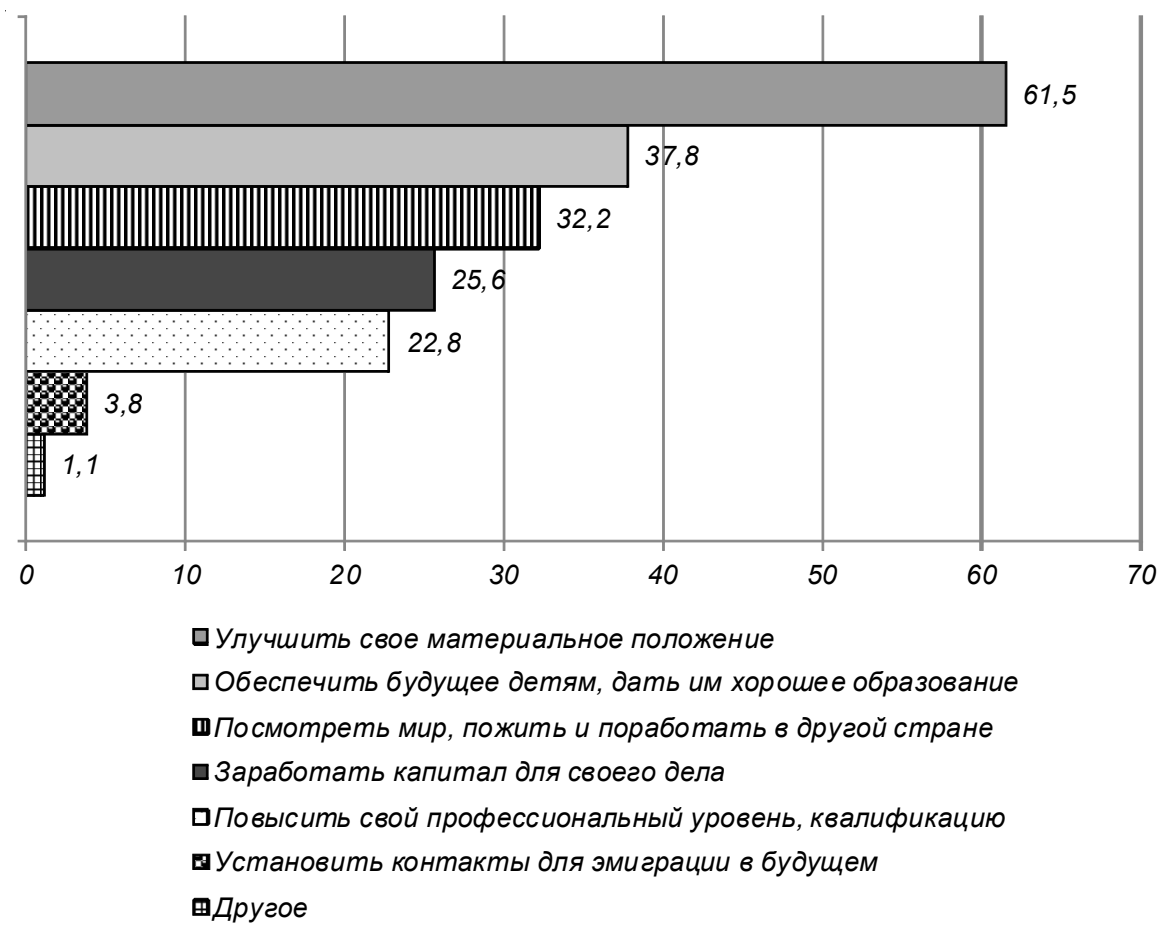

Рис. 13. Основные причины желания выезда из страны за границу с целью временной работы, \%

Примечание. Сумма составляет более 100,0 \%, поскольку респонденты имели возможность выбрать несколько вариантов ответов. 
Основные мотивы желания выехать за границу

на постоянное место жительства в зависимости от вида занятости, сферы деятельности и социального положения респондентов (опрос проводился летом 2018 г.), \%

\begin{tabular}{|c|c|c|c|c|c|c|c|}
\hline Мотивы & $\begin{array}{l}\text { Руководи- } \\
\text { тели разно- } \\
\text { го уровня }\end{array}$ & $\begin{array}{c}\text { Рабочий } \\
\text { (промышлен- } \\
\text { ности, транс- } \\
\text { порта, строи- } \\
\text { тельства } \\
\text { и др.) }\end{array}$ & $\begin{array}{c}\text { Крестья- } \\
\text { нин, рабо- } \\
\text { чий сель- } \\
\text { ского хо- } \\
\text { зяйства }\end{array}$ & $\begin{array}{c}\text { Служащий } \\
\text { специалист } \\
\text { производст- } \\
\text { венной сферы } \\
\text { (инженер, } \\
\text { технолог } \\
\text { и т. д.) }\end{array}$ & $\begin{array}{c}\text { Служащий, } \\
\text { специалист } \\
\text { непроизвод- } \\
\text { ственной } \\
\text { сферы (учи- } \\
\text { тель, врач } \\
\text { и т. д.) } \\
\end{array}$ & $\begin{array}{c}\text { Предпри- } \\
\text { ниматель, } \\
\text { фермер, } \\
\text { самозаня- } \\
\text { тый }\end{array}$ & $\begin{array}{l}\text { Уча- } \\
\text { щийся, } \\
\text { сту- } \\
\text { дент }\end{array}$ \\
\hline $\begin{array}{l}\text { Беспокоит экологиче- } \\
\text { ская ситуация в месте } \\
\text { моего проживания }\end{array}$ & 13,6 & 17,8 & 13,9 & 4,5 & 15,2 & 4,5 & 9,9 \\
\hline $\begin{array}{l}\text { Не удается обеспе- } \\
\text { чить себе достойную } \\
\text { жизнь здесь }\end{array}$ & 59,1 & 66,8 & 45,6 & 48,0 & 78,2 & 67,7 & 44,3 \\
\hline $\begin{array}{l}\text { Неопределенность } \\
\text { профессиональных и } \\
\text { жизненных перспек- } \\
\text { тив } \\
\end{array}$ & 31,8 & 17,9 & 25,5 & 19,1 & 27,6 & 37,4 & 29,3 \\
\hline $\begin{array}{l}\text { Отсутствует возмож- } \\
\text { ность решения жи- } \\
\text { лищной проблемы }\end{array}$ & 18,2 & 19,1 & - & 25,0 & 9,6 & 18,0 & 9,4 \\
\hline $\begin{array}{l}\text { Хочу жить вместе со } \\
\text { своими близкими, } \\
\text { родственниками }\end{array}$ & 4,5 & - & - & - & 8,8 & 8,7 & 5,4 \\
\hline $\begin{array}{l}\text { Хочу обеспечить бу- } \\
\text { дущее моим детям, } \\
\text { дать им хорошее об- } \\
\text { разование }\end{array}$ & 45,4 & 32,8 & 46,0 & 22,4 & 49,8 & 54,8 & 32,1 \\
\hline $\begin{array}{l}\text { Хочу улучшить свое } \\
\text { материальное поло- } \\
\text { жение }\end{array}$ & 22,7 & 45,5 & 86,1 & 47,6 & 53,4 & 62,4 & 59,0 \\
\hline Другое & 9,1 & 10,0 & 25,5 & 10,1 & 10,1 & 5,1 & 1,7 \\
\hline
\end{tabular}

Примечание. Суммы составляют более 100,0 \%, поскольку респонденты имели возможность выбрать несколько вариантов ответов.

Анализ данных таблицы 2 показывает, что в 2018 г. основными мотивами выезда за границу на постоянное место жительства у респондентов - руководителей разного уровня являлись: отсутствие возможности обеспечить себе в Беларуси достойную жизнь $(59,1 \%)$, желание обеспечить будущее детям, дать им хорошее образование $(45,4 \%)$, а также неопределенность профессиональных и жизненных перспектив (30,8 \%).

У рабочих промышленности, транспорта, строительства основными мотивами потенциальной эмиграции явились: отсутствие возможности обеспечить себе в Беларуси достойную жизнь (66,8 \%), желание улучшить свое материальное положение $(45,5 \%)$, а так- же желание обеспечить будущее детям, дать им хорошее образование (32,8 \%).

Несколько иная структура мотивов потенциальной эмиграции выявлена у крестьян, рабочих сельского хозяйства: на первом месте стоит желание улучшить свое материальное положение (86,1 \%), далее - желание обеспечить будущее детям, дать им хорошее образование $(46,0 \%)$ и отсутствие возможности обеспечить себе в Беларуси достойную жизнь (45,6 \%).

Опрошенные служащие и специалисты производственной сферы (инженеры, технологи и т. д.) свое намерение покинуть страну мотивируют отсутствием возможности обеспечить себе в Беларуси достойную жизнь 


\section{БЕЛОРУССКАЯ АКАДЕМИЧЕСКАЯ СОЦИОЛОГИЯ}

(48,0 \%) и желанием улучшить свое материальное положение (47,6 \%). Среди служащих и специалистов непроизводственной сферы (учителя, врачи и т. д.) структура мотивации на эмиграцию следующая: отсутствие возможности обеспечить себе в Беларуси достойную жизнь (78,2 \%); желание улучшить свое материальное положение $(53,4$ \%), обеспечить будущее детям, дать им хорошее образование $(49,8 \%)$.

Учащиеся и студенты основными мотивами выезда за границу на постоянное место жительства назвали желание улучшить свое материальное положение (59,0 \%), отсутствие возможности обеспечить себе в Беларуси достойную жизнь (44,3 \%) и желание обеспечить будущее детям, дать им хорошее образование (32,1 \%). Следует отметить, что значительная доля опрошенных учащихся, студентов (29,3\%) к основным мотивам эмиграции отнесли и такой важный мотив, как неопределенность профессиональных и жизненных перспектив.

Структура мотивов выезда за границу с целью временной работы у представителей основных социально-профессиональных групп населения Беларуси представлена в таблице 3.

Как видим из данных таблицы 3 , у руководителей разного уровня основными мотивами выезда за границу для временной работы являются: желание улучшить свое материальное положение (68,8 \%), обеспечить будущее детям, дать им хорошее образование (50,0 \%), посмотреть мир, пожить и поработать в другой стране (43,8 \%).

Рабочие промышленности, транспорта, строительства основным мотивом временной трудовой миграции называют желание улучшить свое материальное положение (73,0 \%). На втором месте - желание обеспечить будущее детям, дать им хорошее образование $(39,9 \%)$.

Основным мотивом выезда за границу с целью временной работы у крестьян, рабочих сельского хозяйства является желание улучшить свое материальное положение (60,2 \%). Далее идут желание заработать капитал для своего дела $(54,6 \%)$ и желание обеспечить будущее детям, дать им хорошее образование $(43,5 \%)$.

Таблица 3

Структура мотивов временной трудовой миграции в зависимости от вида занятости, сферы деятельности и социального положения респондентов

(опрос проводился летом 2018 г.), \%

\begin{tabular}{|c|c|c|c|c|c|c|c|}
\hline $\begin{array}{l}\text { Мотивы временной } \\
\text { трудовой миграции }\end{array}$ & $\begin{array}{c}\text { Руководи- } \\
\text { тели раз- } \\
\text { ного } \\
\text { уровня }\end{array}$ & $\begin{array}{c}\text { Рабочий } \\
\text { (промыш- } \\
\text { ленности, } \\
\text { транспорта, } \\
\text { строительст- } \\
\text { ва и др.) } \\
\end{array}$ & \begin{tabular}{|c|} 
Крестьянин, \\
рабочий сель- \\
ского хозяй- \\
ства
\end{tabular} & $\begin{array}{c}\text { Служащий, } \\
\text { специалист } \\
\text { производствен- } \\
\text { ной сферы (ин- } \\
\text { женер, техно- } \\
\text { лог и т. д.) }\end{array}$ & $\begin{array}{c}\text { Служащий, } \\
\text { специалист } \\
\text { непроизводст- } \\
\text { венной сферы } \\
\text { (учитель, врач } \\
\text { и т. д.) } \\
\end{array}$ & $\begin{array}{c}\text { Предпри- } \\
\text { ниматель, } \\
\text { фермер, } \\
\text { самозаня- } \\
\text { тый }\end{array}$ & $\begin{array}{l}\text { Уча- } \\
\text { щийся, } \\
\text { студент }\end{array}$ \\
\hline $\begin{array}{l}\text { Заработать капитал } \\
\text { для своего дела }\end{array}$ & 25,0 & 21,8 & 54,6 & 32,5 & 20,7 & 27,5 & 15,4 \\
\hline $\begin{array}{l}\text { Обеспечить будущее } \\
\text { детям, дать им хоро- } \\
\text { шее образование }\end{array}$ & 50,0 & 39,9 & 43,5 & 43,9 & 50,0 & 51,0 & 20,4 \\
\hline $\begin{array}{l}\text { Повысить свой про- } \\
\text { фессиональный } \text { уро- } \\
\text { вень, квалификацию } \\
\end{array}$ & 18,8 & 17,4 & 18,8 & 42,4 & 28,7 & 25,2 & 42,9 \\
\hline $\begin{array}{l}\text { Посмотреть мир, } \\
\text { пожить и поработать } \\
\text { в другой стране }\end{array}$ & 43,8 & 28,5 & 32,8 & 56,2 & 16,5 & 26,5 & 38,1 \\
\hline $\begin{array}{l}\text { Улучшить свое мате- } \\
\text { риальное положение }\end{array}$ & 68,8 & 73,0 & 60,2 & 44,1 & 47,3 & 55,8 & 64,5 \\
\hline $\begin{array}{l}\text { Установить контак- } \\
\text { ты для эмиграции в } \\
\text { будущем }\end{array}$ & 6,3 & 4,2 & 9,9 & 5,8 & - & 6,2 & 4,0 \\
\hline Другое & - & - & - & - & - & - & 3,2 \\
\hline
\end{tabular}

Примечание. Суммы составляют более 100,0 \%, поскольку респонденты имели возможность выбрать несколько вариантов ответов. 
Служащие и специалисты производственной сферы основным мотивом временной трудовой миграции называют желание посмотреть мир, пожить и поработать в другой стране $(56,2 \%)$. На втором месте у них - желание улучшить свое материальное положение $(44,1 \%)$, на третьем - обеспечить будущее детям, дать им хорошее образование (43,9 \%), на четвертом - повысить свой профессиональный уровень, квалификацию (42,4%).

У служащих и специалистов непроизводственной сферы основным мотивом выезда за границу с целью временной работы является желание обеспечить будущее детям, дать им хорошее образование (50,0 \%), вторым по значимости оказалось желание улучшить свое материальное положение (47,3 \%).

Предприниматели, фермеры, самозанятые основным мотивом внешней трудовой миграции называют желание улучшить свое материальное положение $(55,8 \%)$, вторым по приоритетности - желание обеспечить будущее детям, дать им хорошее образование $(51,0 \%)$.

У учащихся и студентов основным мотивом выезда за границу для временной работы является желание улучшить свое материальное положение (64,5\%), далее идут желание повысить свой профессиональный уровень, квалификацию (42,9 \%) и посмотреть мир, пожить и поработать в другой стране (38,1\%).

Таким образом, анализ основных результатов мониторинговых социологических исследований, проведенных Институтом социологии НАН Беларуси за период 2010-2018 гг., показывает, что миграционные настроения населения во многом зависят от состояния социально-экономической ситуации как в Беларуси, так и в странах ближнего и дальнего зарубежья. Так, резкие колебания доли респондентов, желающих выехать из Беларуси для временной работы (16,5\% весной 2014 г. и 9,1 \% весной 2016 г.) объясняются снижением спроса на внешних трудовых мигрантов в России, а также девальвацией российской валюты, что привело к значительному снижению уровня заработной платы у трудовых мигрантов. Следует также отметить как важное обстоятельство - рост конкуренции со стороны трудовых мигрантов из среднеазиатских стран.
В 2017 г. наблюдался значительный рост доли респондентов, планирующих выезд за границу с целью временной работы с $9,1 \%$ в 2016 г. до $14,0 \%$. В этой связи можно констатировать, что отмеченное в 2016 г. резкое падение доли респондентов, планирующих выезд за границу с целью временной работы, имело краткосрочный характер. Как только социально-экономическая ситуация в России начала улучшаться, доля респондентов, планирующих выезд за границу с целью временной работы, опять вернулась к среднему годовому показателю (12,0-14,0 \%), характерному для многих лет наблюдений.

Как тенденцию, требующую к себе особого внимания и анализа, следует отметить наблюдающееся в последние годы превышение доли респондентов, желающих эмигрировать в зарубежные страны, над долей респондентов, имеющих планы выехать за рубеж на заработки. Так, если в 2014 г. доля респондентов, нацеленных на внешнюю трудовую миграцию, почти в 3 раза превышала долю респондентов, желающих эмигрировать из страны, то в 2018 г. доля респондентов, желающих выехать за границу на постоянное место жительства, превосходила долю потенциальных трудовых мигрантов на 1,7 п.п. Следует отметить, что среди респондентов в возрасте до 29 лет превышение доли респондентов, желающих выехать за границу на постоянное место жительства, над долей потенциальных трудовых мигрантов составило 6,5 п.п. Если данная тенденция найдет продолжение и в последующие годы, то это будет означать важный поворот в миграционных установках белорусской молодежи.

\section{СПИСОК ЛИТЕРАТУРЫ}

Миграция... 2013 - Миграция населения в Республике Беларусь в 2012 году: стат. бюллетень. Минск, 2013.

Миграция... 2017 - Миграция населения в Республике Беларусь за 2016 год: стат. бюллетень. Минск, 2017.

Миграция... 2018 - Миграция населения в Республике Беларусь за 2017 год: стат. бюллетень. Минск, 2018. 
О естественном движении населения... 2018 - О естественном движении населения по Республике Беларусь за 2017 год: стат. бюллетень. Минск, 2018.

Основные итоги... 2009 - Основные итоги миграции населения Республики Беларусь: стат. бюллетень. Минск, 2009.

Основные итоги... 2010 - Основные итоги миграции населения Республики Беларусь: стат. бюллетень. Минск, 2010.

Основные итоги... 2011 - Основные итоги миграции населения Республики Беларусь: стат. бюллетень. Минск, 2011.

Основные итоги... 2012 - Основные итоги миграции населения Республики Беларусь: стат. бюллетень. Минск, 2012.

Основные итоги... 2014 - Основные итоги миграции населения в Республике Беларусь за 2013 год: стат. бюллетень. Минск, 2014.

Основные итоги... 2015 - Основные итоги миграции населения в Республике Беларусь за 2014 год: стат. бюллетень. Минск, 2015.

Основные итоги... 2016 - Основные итоги миграции населения в Республике Беларусь за 2015 год: стат. бюллетень. Минск, 2016.

По данным МВД... web - По данным МВД, за рубежом работают порядка 300 тысяч белорусов // http://news.tut.by/society/375768.html.

Сведения... web - Сведения о численности граждан государств-членов Евразийского экономического союза, въехавших в Российскую Федерацию для осуществления трудовой деятельности за 20122017 годы // http://www.eurasiancommission.org/ $\mathrm{ru} /$ act/finpol/migration/Documents/графики\%20по \%20таблице.pdf.

Ткачева 2010 - Ткачева Н.A. Социологическая концепция миграционной политики региона в системе национальной безопасности: дис. ... д-ра социол. наук: 22.00.05. Тюмень, 2010.

\section{REFERENCES}

Population shift in Republic of Belarus in 2012: bulletin. Minsk, 2013.

Population shift in Republic of Belarus for 2016 : bulletin. Minsk, 2017.

Population shift in Republic of Belarus for 2017 : bulletin. Minsk, 2018.

About the natural movement of the population on Republic of Belarus for 2017: bulletin. Minsk, 2018.

Main results of population shift of Republic of Belarus: bulletin 2009. Minsk, 2009.

Main results of population shift of Republic of Belarus: bulletin 2010. Minsk, 2010.

Main results of population shift of Republic of Belarus: bulletin 2011. Minsk, 2011.

Main results of population shift of Republic of Belarus: bulletin 2012. Minsk, 2012.

Main results of population shift of Republic of Belarus: bulletin 2013. Minsk, 2014.

Main results of population shift in Republic of Belarus for 2014: bulletin. Minsk, 2015.

Main results of population shift in Republic of Belarus for 2015: bulletin. Minsk, 2016.

According to the Ministry of Internal Affairs, about 300 thousand Belarusians. URL: http:// news.tut.by/society/375768.html.

Data on the number of citizens of the state members of the Eurasian Economic Union which drove to the Russian Federation for implementation of work for 2012-2017. URL: http:// www.eurasiancommission.org/ru/act/finpol/ migration/Documents/графики according to таблице.pdf.

Tkachyova N.A., 2010. The sociological concept of migration policy of the region in the system of a homeland security: the thesis for a degree of the doctor of sociological sciences 22.00.05. Tyumen.

\section{Information about the Authors}

Mikchail I. Artyukhin, Candidate of Scienses (Philosophy), Associate Professor, Head of the Migration Monitoring Center of Research and Academic Staff, Institute of Sociology of the National Academy of Sciences of Belarus, Surganova St., 1/2, 220072 Minsk, Republic of Belarus, art47@mail.ru, https://orcid.org/0000-0003-4458-5576

Sergey A. Pushkevich, Researcher, Migration Monitoring Center of Research and Academic Staff, Institute of Sociology of the National Academy of Sciences of Belarus, Surganova St., 1/2, 220072 Minsk, Republic of Belarus, pushkevich@gmail.com, https://orcid.org/0000-0003-3087-3876

Ella M. Shurok, Researcher, Migration Monitoring Center of Research and Academic Staff, Institute of Sociology of the National Academy of Sciences of Belarus, Surganova St., 1/2, 220072 Minsk, Republic of Belarus, ella_1@tut.by, https://orcid.org/0000-0002-4395-300X 
М.И. Артюхин, С.А. Пушкевич, Э.М. Щурок. Миграционные установки социально-демографических групп

\section{Информация об авторах}

Михаил Иванович Артюхин, кандидат философских наук, доцент, руководитель Центра мониторинга миграции научных и научно-педагогических кадров, Институт социологии НАН Беларуси, ул. Сурганова, 1/2, 220072 г. Минск, Республика Беларусь, art47@mail.ru, https://orcid.org/0000-0003-4458-5576

Сергей Александрович Пушкевич, научный сотрудник Центра мониторинга миграции научных и научно-педагогических кадров, Институт социологии НАН Беларуси, ул. Сурганова, 1/2, 220072 г. Минск, Республика Беларусь, pushkevich@gmail.com, https:/orcid.org/0000-0003-3087-3876

Элла Михаловна Щурок, научный сотрудник Центра мониторинга миграции научных и научно-педагогических кадров, Институт социологии НАН Беларуси, ул. Сурганова, 1/2, 220072 г. Минск, Республика Беларусь, ella_1@tut.by, https://orcid.org/0000-0002-4395-300X 